\title{
Utilization of Facility Management Concept in Real Estate Management
}

\author{
Piotr BARTKOWIAK * and Anna GÓRSKA \\ Poznań University of Economics and Business, Poznań, Poland; piotr.bartkowiak@ue.poznan.pl; \\ anna.gorska@ue.poznan.pl \\ * Correspondence: piotr.bartkowiak@ue.poznan.pl
}

\begin{abstract}
The aim of the study is to present the concept of facility management in real estate management. The article attempts to define the concept of facility management, a historical outline, the most important assumptions and the standardization process in Poland and in the world. The authors presented the activities of the facility manager in relation to the actions of the property manager - what distinguishes them, what activities fall within the scope of their work, in what context we can analyse them and what features should stand out. The analysis presents changes that occur on the real estate market in Poland in relation to the requirements of owners and users in relation to the space occupied. The conclusion is that the ongoing, dynamic changes resulting from Poland's pursuit (in the footsteps of other European countries) to the development of service society will increase the demand for services in the field of facility management.
\end{abstract}

Keywords: real estate management; facility management; real estate maintenance; real estate market

JEL Classification: R31; R39; L85

\section{Introduction}

Real estate along with the entire infrastructure, and above all, users of these properties require a special form of management. Real estate management is not only about issues related to technical and operational inspections of devices or fire safety, but also to the needs of people residing and working in a building in terms of facilities related to its use. The growing market of construction products and technologies connected with real estate causes that modern facilities require special knowledge from the person dealing with their management. Also entities existing on the market and investing in the rental market expect top-level service ensuring a return on invested capital and user satisfaction. Relations between property management and facility management are also often discussed, as well as their relationship with business strategy (Atkin and Brooks 2015).

Therefore, the purpose of the article is to indicate the difference between property management and management of facilities and activities that differentiate them. The authors also attempted to indicate the direction of Facility Management development in Poland.

The article is the result of analysis conducted by the authors of previous literature and their publication (Bartkowiak and Górska 2019; Bartkowiak and Górska 2020).

\section{The Development of the Concept of Facility Management}

The concept of Facility Management appeared in the mid-1970s, when office furniture manufacturers in the United States said that in the situation of existing, competitive market competition, the use of products is optimally dependent on the links between facilities, that is, furniture features and productivity of people who are their users (Pruszkowski 2009).

Today, facility management is a concept known and used not only on the international market, but also in Poland. The interdisciplinary nature of the activity has also caused that its statutory regulation is difficult, but measures are being taken to set standards and certification. (DessoulavyŚliwiński and Gabryelczyk 2016) For this reason, the International Facility Management Association defines Facility Management as a profession covering many disciplines to ensure the functionality, 
comfort, safety and efficiency of the developed environment by integrating people, places, processes and technologies. (IFMA).

In Poland the facility manager's activity has not been regulated by law, however the norm EN15221 published in 2012 by the European Committee for Standardization had an impact on the introduction by the Polish Standardization Committee of PN-EN 15221-1:2012P, which defines Facility Management as management actions aimed at "integrating processes within the organization as well as providing and developing agreed services that support and increase the effectiveness of the organization's core activities." (Standard Facility Management PN-EN 15221 2015) The norm referred to the essence of Facility Management by formulating its main assumptions and elements concerning (Foryś 2014):

1. Terms and definitions - provisions regarding standardization of concepts and understanding of the scope of Facility Management, in order to support the relationship between the client and the service provider in Facility Management

2. Guidelines for the preparation of Facility Management agreements - defining provisions related to agreements and contracts in Facility Management, as well as the liability of both parties and the scope and level of services performed

3. Quality management - guidelines for measuring quality, but also improving it and achieving the best results

4. Taxonomy, classification and structures in infrastructure management - the concept of classifying products, as well as linking individual elements and structures in infrastructure management

5. Process approach - guidelines related to the development and improvement of processes that support basic processes

6. Surface measurement - definition of common standards for measuring surfaces in buildings and outside buildings, as well as definitions, terms and methods for measuring space and volume in buildings

7. Benchmarking - definition of deadlines, definitions, but also benchmarking methods. Basics defining quality, service performance and satisfaction

Starting from 2017, further parts of the international Facility Management (ISO) standard have been published as a result of the work of the International Committee for Standardization.

The market of Facility Management is a relatively young market in Poland, and the approaches and understanding of the services offered are different, therefore the process of normalization of concepts and activities in the area of Facility Management will be an important tool to support communication when determining the terms of cooperation.

Thus, it should be emphasized that the activities of the facility manager are primarily to support and improve the efficiency of the organization's basic activities. Therefore, its activities are aimed at improving the quality of basic services. However, the division of activities related to the basic and auxiliary activities, as well as the scope of services and their implementation are determined between the supplier and the client. it according to art.

\section{Facility Management in the Context of Property Management}

Real estate management is in accordance with article 184b of the Act of 21 August 1997 on Real Estate Management "making decisions and activities aimed at ensuring rational property management, in particular:

- Proper economic and financial economy of real estate

- Safety of use and proper use of real estate

- Proper energy management within the meaning of energy law regulations

- Day-to-day real estate administration

- Maintaining the real estate in a non-deteriorated condition in accordance with its intended use

- Reasonable investment in real estate.“ (Act. on Real Estate Management of 21 August 1997) 
Therefore, property management is perceived as a process of traditional building administration, where the main activities of the manager are focused on the building and its functioning. However, consideration should be given to the level of effectiveness of these activities. Professor Ewa KucharskaStasiak (2006) defines real estate management in a narrower and wider approach. The narrower approach to real estate management is identified with administration - maintenance and maintenance of real estate, covering operating costs and preventing rent arrears. The wider approach perceives real estate management as a process of creating visions and goals, both short- and long-term, in the prevailing market environment. Management is not only administrative tasks, but also activities aimed at increasing the value of the real estate. The second part of the definition shows the desirability of using the Facility Management concept in real estate management as management of facilities. Progress in both construction technology and equipment used in buildings, as well as the changing expectations of both owners, investors and users of facilities has resulted in the evolution of the perception of property management. Today, the property is not only a building, but mainly users and facilities offered in connection with the operation of real estate:

- in the case of residential buildings - residential purposes for running a household, leisure, family atmosphere or raising children

- in the case of commercial real estate - support, and even relieving both the users and the owner from the need to take care of spatial, technical and financial issues arising from the space occupied or rented (Pruszkowski 2009)

One of the basic problems associated with real estate management is the lack of a specific mission for real estate, and even the lack of strategies and goals. Many people dealing with real estate limit their operation to the activities required of them by law and so-called "extinguishing fires", which usually generates higher costs than preventive actions. Both the facility manager and the administrator who is trying to act in accordance with the Facility Management concept should define the strategy of action and then take actions related to its implementation and accomplishment. This concept means that property management includes not only building management, but also strategic management in the context of external factors that affect the property.

Strategic management is one of the most important aspects of Facility Management and refers to the elements of planning and then implementation and control of the adopted strategy taking into account the life cycle of real estate as well as the costs and benefits resulting from its implementation.This section is usually divided by subheadings. It should provide a concise and precise description of the results, their interpretation as well as the experimental conclusions that can be drawn. Include all the evidence needed to answer the questions/hypotheses you investigated. Present the results in a sequence that will logically support (or provide evidence against) your hypothesis, or answer your scientific question stated in the Introduction.

Facility manager is responsible for adjusting real estate management strategies to the property life cycle, where:

- The facility is adapted to the needs of users in the first phase, removing minor defects and errors created at the design or construction stage. In this phase, no investment activities are undertaken as this is a new facility

- Activities related to the exchange of selected technical equipment or systems for newer ones are carried out in order to optimize the renovation management and rationalization of costs as well as to meet the expectations of users

- Requires specific financial outlays resulting from the adaptation of the property to changes in the market environment and changing market standards

Another factor that the facility manager takes into account when defining the strategy are property maintenance costs. The ideal situation would be to apply the Facility Management concept already at the design and construction stage of the facility, which would allow the use of equipment and installations that would allow to achieve significant efficiency in the operation of the facility 
without the need for repairs and changes in the future. However, if this option is not taken into account, the activities of the facility manager include the identification of costs (target amount of rent and other charges from tenants), categorization of costs (goal being optimization of costs and resources), and in the case of investments in the investment efficiency calculation (goal is to optimize the total costs associated with devices or installations). An additional advantage of the investment is to gain an advantage over the competition by offering users a more modern technology used in the building. The last stage, including reduction and rationalization of costs, is the coordination of costs and technological solutions (especially in intelligent buildings) in order to achieve their optimal level and synergy effect (Śliwiński and Śliwiński 2006).

Both the applied management strategy and activities related to the reduction of costs contribute to the increase in the value of real estate. The value of the real estate is not constant throughout the life cycle of the property - it changes along with the way the object is used and maintained. Therefore, active activities in the field of cost rationalization, adjustment of the building's function to market requirements and facilities for real estate users and the search for possible sources of income cause an increase in income from real estate, and thus an increase in its value.

In relation to operational factors, the activities within Facility Management can be divided into three groups:

- economic and financial - financial issues and planned investments

- technical - building management and real estate devices and installations

- infrastructure - additional services provided to real estate users (Dessoulavy-Śliwiński and Gabryelczyk 2016)

Economic and financial activities are activities related to relieving both the owner and users from the need to develop a property development plan, control budgets, carry out controls of concluded agreements and payments related to real estate and all financial activities. It should also be emphasized that as a result of the evolution of property management, the management of leases characterized by specialization related to a specific type of real estate was identified, including the scope of tenantoriented marketing, property development focused on property rental, financial and insurance institutions supporting business activity, rental and evolution of the tenant status, which is not perceived as a "tenant" and "periodic owner"(Pruszkowski 2009).

Technical activities include operations related to building management from the level of devices installed in the facility and attempts to integrate them into one system that supports the entire facility, i.e. an intelligent home. Such buildings are modern objects (not only in terms of architecture and construction, but also in terms of equipment in installations), which are distinguished by features such as: comfort, safety, functionality, aesthetics and savings in operation. The "intelligence" of objects is demonstrated by modern technology that allows control of any installations (heating, lighting, air conditioning, ventilation) depending on the ambient conditions and the selected program. This allows you to optimize the reduction of heating, cooling and electricity consumption by up to several dozen percent. However, it requires coordinating all systems in one place.

From the management point of view Facility Management can be considered from the three aspects:

- object - building, construction, but also a production complex with network technical devices

- amenities - activities aimed at supporting basic processes in the organization by creating a comfortable working atmosphere and supporting people in performing their basic duties

- technological innovations - introducing changes and innovations in facilities and devices (Dessoulavy-Śliwiński and Gabryelczyk 2016; Sroka and Meyer 2019).

It is the management of amenities (or facilities) that is what distinguishes Facility Management from basic property management. Amenities are in other words all activities that allow you to achieve the desired level of functionality, quality, health, safety or minimizing costs. (Śliwiński and Śliwiński 2006) Therefore, the task of the facility manager is to create such facilities that meet the expectations of 
the owner and users at the same time, taking into account the conditions and functional capabilities of the property. All activities performed as part of Facility Management can be carried out by the facility managers independently, while in the case of some of them (e.g., economic service, protection of facilities or cleaning) induce facility managers to use the outsourcing of services. The advantage of outsourcing is lower costs, the use of knowledge and skills of an external company, higher quality, and sometimes also the physical inability to provide services by the facility manager or his company.

The formulated scope of tasks carried out in this way leads to the fact that the facility manager person should be distinguished by a number of competences, which were defined by the International Facility Management Association in order to grant the Certified Facility Manager certificate. Based on research conducted in over 60 countries, the key competences of the facility manager include the following capabilities:

1. Leadership and strategic

2. Using new concepts of real estate management, including social responsibility and sustainable development

3. Interpersonal

4. Technical and technological

5. Innovative

6. Designing

7. Taking into account the risk

8. Interpersonal communication (IFMA)

The competences presented emphasize that in addition to activities related to technical maintenance of the building and administration, what is also important is management skills which focus on real estate users and their needs as well as the needs of other stakeholders.

\section{Directions of Facility Management Development in Poland}

"Facility management has evolved from a strategically irrelevant business task to a highly professionalised sector, which is worth billions in many countries." This sector includes, among others: office buildings, banks, financial institutions, trade, shopping centers, production buildings, production halls, warehouses, hospitals, clinics, social institutions, public administration, military, schools, universities, public buildings, conference centers, museums, hotels, etc. (Stickelberger and Erdpresser 2018). The intense development of the real estate market in Poland in recent years and the growing interest of foreign investors meant that many multinational corporations that expect high quality of services have appeared on the real estate market (especially commercial). (Foryś 2006) Therefore, it is necessary to apply international Facility Management standards in real estate management. Requirements for administrators are growing, and the range of services they offer is expanding.

As a result, more and more people are employed in the services sector, and real estate is increasingly the most important property asset of companies. At the same time, expenses related to the management of these assets and investment expenditures increase (Śliwiński and Śliwiński 2006; Jaworek, Karaszewski, and Szałucka 2018).

The changes taking place on the property management services market have changed the perception of the property manager (especially in case of modern commercial buildings) and its services. Services offered on the market include more and more elements. Therefore, the legal functions of the manager are now not only to familiarize with lease agreements and verify their entries, but also to conclude contracts with tenants, which are usually the result of long-term negotiations, and the way they are constructed should not raise any doubts in the future when enforcing their provisions. The manager becomes the intermediary between the owner and the developer and the enforcer of the rights to complete the investment. It is also responsible for debt collection to ensure financial liquidity for property owners. Technical activities do not only include compliance with the law, but also activities related to improving the technical efficiency of the building, coordinating the work of all devices on the site and increasingly certification of buildings in accordance with the Green Building 
idea, e.g. LEED, BREAM certificates. Property owners also expect that in the process of arranging or modernizing the building, the facility manager will coordinate the works performed on the site so that they do not hinder the activity of other users, they are in line with, among others, with fire regulations, health and safety, and will consult problems related to the implementation of individual stages. Not only the owner, but also the users require that the costs related to the maintenance of the property be minimized and the financial resources possessed are rationally spent. In its financial and economic activities the facility manager should strive to increase real estate income by looking for additional sources of profit and sources of investment financing for real estate (Najbar 2013).

Competition on the market, as well as an increase in the requirements of property owners, means that it is necessary to offer more and more services. Moreover, deregulation of the property manager's profession in 2014 caused an increase in the number of professional organizations and associations related to the profession of the manager, which may have a significant impact on the development of the real estate market. On the basis of this, it can be stated that the market of real estate management services in Poland is changing rapidly, which in turn leads to an increase in the importance of Facility Management mainly in large cities, where modern, "smart" facilities and shopping centres are emerging that require focus on searching for the best real estate management conditions and achieving the assumed goals related to the organization (Foryś 2014). Transparency Market Research reports "that the Polish facilities management market has excellent growth prospects in the next few years. The market is expected to exhibit a healthy 9.7\% CAGR from 2016 to 2024, owing to which, the market, which held an opportunity of US $\$ 14.34$ bn in 2015, is expected to rise to US $\$ 32.62$ bn by 2024" (Transparency Market Research 2020). It is important to involve the facility manager person already at the stage of project creation, where it may have an impact on making optimal decisions in the field of building architecture, construction technology, equipping with equipment, and then participation in acceptance and training of facilities thanks to which an object with the best adaptation to people working in it will be created, taking into account both functionality, interior arrangement, organizational and economic issues.

\section{Conclusions}

The economic and technological development as well as the increase in foreign investments mean that complex management of facilities will develop dynamically. The factors that affect this are, firstly, investors and foreign funds that are eager to invest on the Polish market. They expect the real estate to bring profits. Therefore, a narrow view of property management focused on administrative activities and daily maintenance of the object is not enough. They expect to develop strategies and activities aimed at minimizing and rationalizing costs. On the other hand, the growing possibility of real estate related to modern technology, interior finishing, external companies with services that can be used and growing competition among managers means that using the services of people who have the knowledge and skills to use this potential is desirable on the market.

Facility Management is primarily interpersonal relations, the ability to coordinate activities and professional knowledge of real estate. The current main challenge facing organizations associated with Facility Management is to educate young people on the best practices in Facility Management.

The Polish market of Facility Management, despite the fact that it is dynamically developing, occurs mainly in large cities, and even there, not all owners and investors on the market are aware of the benefits of employing a facility manager. However, we anticipate that with the constant development of the market and the expectations of users, the activities of property managers will be increasingly performed in accordance with the Facility Management concept.

\section{References}

Atkin Brian, and Brooks Adrian. 2015. Total facility management. 4th ed. Chichester: John Wiley \& Sons, Ltd., p. 21. Bartkowiak Piotr, and Górska Anna. 2020. Zróżnicowanie kosztów utrzymania i wyposażenia mieszkań w zależności od typu zasobu mieszkaniowego w Polsce. In Kierunki rozwoju rynku nieruchomości. Edited by Piotr Bartkowiak. Poznań: Poznań University of Economics and Business, pp. 117-134. 
Bartkowiak Piotr, and Górska Anna. 2019. Zarządzanie nieruchomościami w odniesieniu do koncepcji Facility Management. In Granice rynku nieruchomości. Wyzwania i praktyka. Edited by Piotr Bartkowiak. Poznań: Poznań University of Economics and Business, pp. 15-25.

Dessoulavy-Śliwiński Bartłomiej, and Gabryelczyk Renata. 2016. Facility Management 2.0. Infrastruktura $i$ nieruchomości. Warszawa: Grupa Medium.

Foryś Iwona. (ed.) 2014. Zarzadzanie nieruchomościami handlowymi. Warszawa: Poltext.

Foryś Iwona. 2006. Zarzadzanie nieruchomościami komercyjnymi. Warszawa: Poltext.

IFMA. (2017). Executive Summary the Job Task Analysis for the Certified Facility Manager (CFM) Certification Examination. Available online: http://cdn.ifma.org/sfcdn/docs/default-source/default-documentlibrary/2016-gjta-executive-summary.pdf?sfvrsn=0 (accessed on 30 November 2019).

Jaworek Małgorzata, Karaszewski Włodzimierz, and Szałucka Małgorzata. 2018. Greenfield or acquisition entry? An impact of foreign direct investment on the competitiveness of polish investors. Entrepreneurial Business and Economics Review: 6(2), 137-152. https://doi.org/10.15678/EBER.2018.060207.

Kucharska-Stasiak Ewa. 2006. Nieruchomość w gospodarce rynkowej. Warszawa: PWN.

Najbar Katarzyna. 2013. Rynek ustug zarządzania nieruchomościami. Series: Nieruchomości. Warszawa: Poltext.

Nor Noor Azman Mohamat. Mohammed Abdul Hakim, and Alias Buang. 2014. Facility Management History and Evolution. International Journal of Facility Management: 5(1), 1-21.

Poland. Act of 21 August 1997 on Real Estate Management (Dz. U. 1997 No. 115,Pos. 741).

Pruszkowski Leszek. 2009. Zarzadzanie procesami pomocniczymi w przedsiębiorstwie. Koncepcja Facility Management. Płock: Państwowa Wyższa Szkoła Zawodowa w Płocku.

Sroka Włodzimierz, and Meyer Natanya. 2019. Reengineering the way to do business: perspectives from standpoints of innovation, production and performance. Engineering Management in Production and Services: 3, 69-70. https://doi.org/10.2478/emj-2019-0028.

Standard Facility Management PN-EN 15221. 2015. Available online: www.menpresa.pl/images/articles (accessed on 10 January 2020).

Stickelberger Tobias, and Erdpresser Andreas. 2018. IC Market Tracking. Facility Services in DACH 2018. Interconnection Consulting. Available online: www.interconnectionconsulting.com/wpcontent/uploads/2017/09/Offer-Facility-Services-in-DACH-2018.pdf (accessed on 29 January 2020).

Śliwiński Artur, and Śliwiński Bartłomiej. 2006. Facility Management. Warszawa: Wydawnictwo C.H. Beck.

Transparency Market Research. 2020. Poland Facilities Management Market: Snapshot. Available online: www.transparencymarketresearch.com/poland-facilities-management-market.html (accessed on 29 January 2020). 